\title{
Added Prognostic Value of Plaque Burden to Computed Tomography Angiography and Myocardial Perfusion Imaging
}

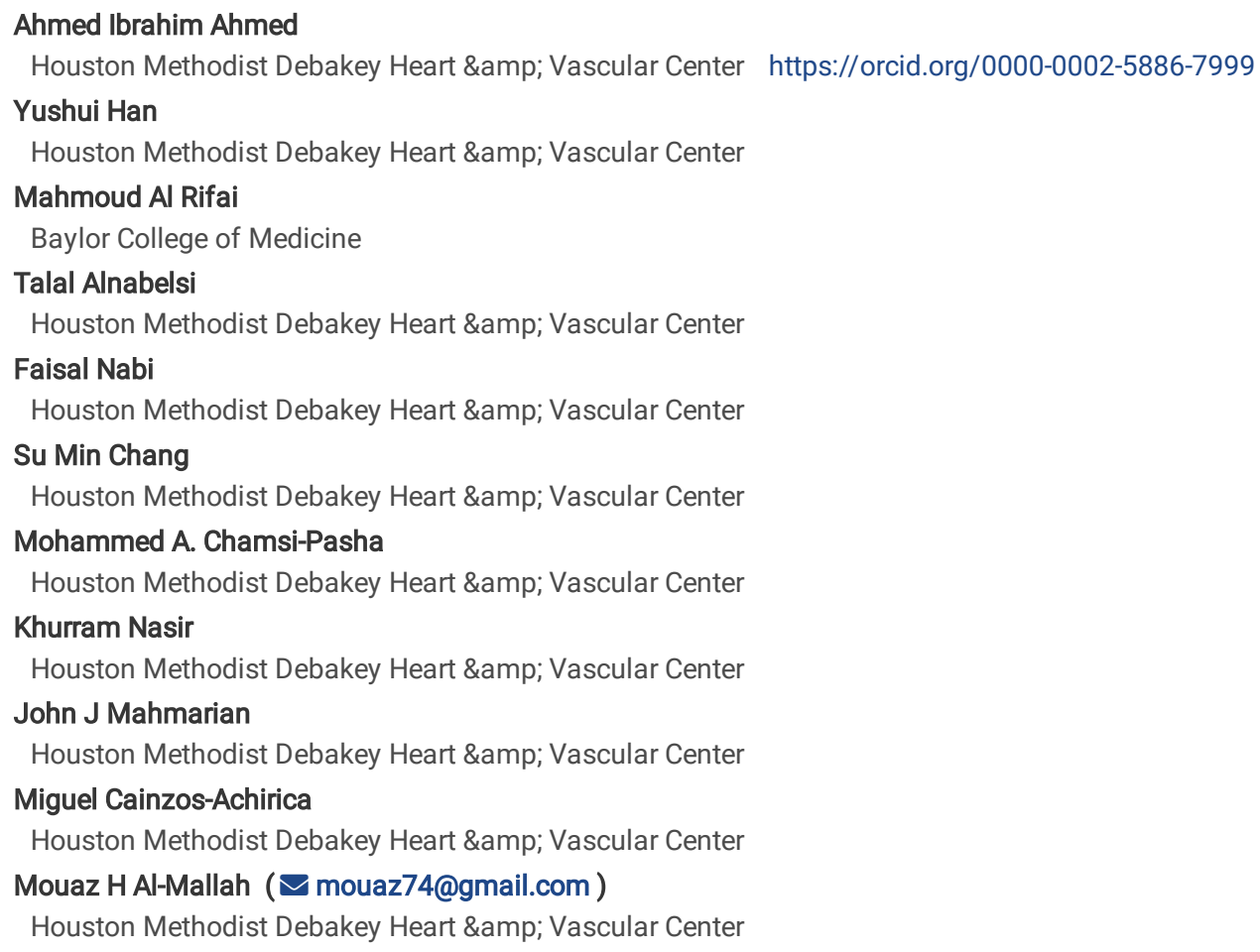

\section{Research Article}

Keywords: SPECT, MPI, CCTA, SIS, plaque burden

Posted Date: April 19th, 2021

DOI: https://doi.org/10.21203/rs.3.rs-421761/v1

License: (c) (i) This work is licensed under a Creative Commons Attribution 4.0 International License. Read Full License 


\section{Abstract}

Purpose: Cardiac computed tomographic angiography (CCTA) - derived measures of coronary artery disease (CAD) burden such as segment involvement score (SIS), which quantifies the number of segments with plaque, have been shown to independently predict incident cardiovascular events. We aimed to compare the added prognostic value of plaque burden to CCTA anatomic assessment and single photon emission computed tomography (SPECT) physiologic assessment in a high-risk cohort undergoing both tests.

Methods: Consecutive patients who underwent clinically indicated CCTA and SPECT myocardial imaging for suspected CAD at a tertiary care cardiology practice were included. Stenosis severity and SIS were determined from CCTA, and presence of ischemia was determined from SPECT. Patients were followed for major adverse cardiovascular events (MACE, inclusive of all-cause death, non-fatal myocardial infarction, and percutaneous coronary intervention or coronary artery bypass grafting 90-days after imaging test.)

Results: A total of 956 patients were included. Mean age was $61.1 \pm 14.2$ years, $54 \%$ were men, $89 \%$ had hypertension, $81 \%$ had diabetes, $84 \%$ had dyslipidemia and $56 \%$ had recorded chest pain. Obstructive stenosis (left main $\geq 50 \%$, all other coronary segments $\geq 70 \%$ ) and ischemia were observed in similar number of patients (14\%). After a median follow-up of 31 months, 102 patients (11\%, 29.2 events per 1000 person-year) experienced a MACE. In multivariable Cox regression models, SIS significantly predicted outcomes and improved risk discrimination in models with CCTA obstructive stenosis (HR 1.15 95\% Cl 1.09 - 1.21 p=<0.001; Harrel's C 0.74, p=0.008) and SPECT ischemia (HR 1.14 95\% Cl 1.08 - 1.20, p<0.001; Harrel's C 0.76, p=0.019). Results were consistent using subgroups by plaque composition (calcified vs non-calcified) and lower thresholds of CCTA stenosis.

Conclusion: Our results suggest that in high-risk patients with suspected CAD, plaque burden adds incremental prognostic value over established measures in predicting incident cardiovascular outcomes.

\section{Introduction}

Coronary computed tomography angiography (CCTA) is currently guideline-endorsed for diagnosing suspected coronary artery disease (CAD) in lowintermediate risk patients. [1] CCTA enables the anatomic assessment of coronary artery stenosis on par with invasive angiography. Improvements in resolution have also allowed identification of high-risk plaque characteristics that portend an increased risk of adverse cardiac events. [2] Studies have shown high sensitivity and negative predictive value, enabling the accurate rule-out of CAD when tests are normal.[3] Furthermore, a CCTA based assessment has been shown to significantly reduce the rate of death from CAD or nonfatal myocardial infarction, and reduce downstream costs. [3,4]

Single photon emission computed tomography (SPECT) myocardial perfusion imaging (MPI) has an established role in both the accurate detection of ischemia and identification of patients at high risk of future cardiovascular events. [5] Data from several studies and prospective registries have demonstrated up to 5-6 fold increase in cardiac death or non-fatal myocardial infarction (MI) in patients with an abnormal SPECT.[5] This predictive role has also been demonstrated in subgroups of age, sex, and those with diabetes. [6]

More recently, the burden of CAD is increasingly being recognized as an important determinant of patients' outcomes. Studies on measures of CAD burden obtained from CCTA such as segment involvement score (SIS - the total number of coronary artery segments with plaque) have shown how patients can be stratified across a continuum of risk above a more simplistic binary classification by the presence of stenosis. [7] Furthermore, studies have shown that degree of stenosis and high-risk plaque features were no longer significantly predictive of outcomes when accounting for burden of disease. [8]

Most studies on anatomical versus functional assessment in patients with suspected CAD have focused on the diagnostic accuracy of various imaging modalities without accounting for coronary atherosclerosis burden. We therefore aimed to assess the incremental prognostic value of the burden of atherosclerosis over CCTA anatomic assessment and SPECT functional assessment in patients with suspected CAD.

\section{Methods}

\section{Study Population}

The study population consisted of 956 consecutive patients presenting to our institution from January 1, 2010 to June 22, 2020 who underwent CCTA and SPECT MPI within 180 days of each other for evaluation of suspected CAD. Patients with prior percutaneous coronary intervention (PCI), coronary artery bypass grafts (CABG) and left ventricular assist devices (LVAD) were excluded. Also excluded were patients who underwent revascularization between the two tests. Patients with congenital abnormalities of the coronary tree and those with severe valvular abnormalities were also excluded. Approval from the Institutional Review Board at the Houston Methodist Academic Institute was obtained prior to the start of the study and informed consent was waived due to the retrospective nature of the study.

\section{Assessment of Covariates}

Information on sociodemographic variables (age and gender), medical history, comorbidities (hypertension, diabetes, dyslipidemia), smoking history and medication use was obtained using chart review of all patient records in electronic medical records within 30 days before or after imaging. 
CCTA scans were obtained using $3^{\text {rd }}$ generation SOMTAM FORCE Scanner (Siemens, Forchheim, Germany) after 2016 ( $\left.n=530\right)$ and Phillips 64 slice CT (Philips Healthcare, Amsterdam, Netherlands) before $2016(n=426)$. Image acquisition was performed in accordance with the Society of Cardiovascular Computed Tomography (SCCT) guidelines.[9] Intravenous metoprolol was administered for patients with a heart rate >=65 beats/min and sublingual nitroglycerin $0.4 \mathrm{mg}$ was administered immediately before image acquisition. During image acquisition, $60-100 \mathrm{cc}$ of contrast was injected, followed by saline flush. Axial scans were obtained with prospective electrocardiographic gating. Image acquisition was prescribed to include the coronary arteries, left ventricle and proximal ascending aorta.

Images were assessed with a 3-dimensional workstation using one of several post-processing methods including axial, multiplanar reformat, maximum intensity projection and cross-sectional analysis. Type and location of lesion were visually evaluated using an 18-segment model according to SCCT guidelines. [10] In each segment, atherosclerosis was defined as tissue structures $>1 \mathrm{~mm}^{2}$ within the coronary artery lumen or adjacent to the lumen that could be discriminated from pericardial tissue, epicardial fat or vessel lumen itself.

Percent coronary stenosis was quantified based on a comparison of the luminal diameter of the segment exhibiting obstruction to the luminal diameter of the most normal-appearing site and classified as none ( $0 \%$ ), mild ( $1 \%$ to $49 \%)$, moderate $(50 \%$ to $69 \%)$, or severe ( $\geq 70 \%)$ based on degree of narrowing of the luminal diameter. Anatomically obstructive CAD by CCTA was defined as $\geq 50 \%$ in the left main artery and $\geq 70 \%$ stenosis severity in proximal, mid and distal branches of the left anterior descending, left circumflex and right coronary artery without including side branches. Findings were reported using American College of Cardiology Coronary Artery Disease Reporting \& Data System (CAD-RADS). [11]

Segment involvement score was used to quantify burden of disease using CCTA. Using an 18-segment coronary artery model, each segment was individually scored as 0 or 1 based on the presence of plaque irrespective of the degree of stenosis. The sum of all involved segments was calculated for each patient. A Hounsfield unit threshold of $<130$ was used to classify plaques as non-calcified plaque (NC SIS). For those with Hounsfield unit $>=130$, plaques were classified as calcified (C SIS), mixed (M SIS) or calcified or mixed (C/M SIS) based on uniformity of calcification.

\section{SPECT MPI}

SPECT MPI scans were obtained using INTIVO scanner (Siemens, Forchheim, Germany) or Phillips Brightview scanners (Philips Healthcare, Amsterdam, Netherlands.) Image acquisition was performed in accordance with the American Society of Nuclear Cardiology guidelines. [12] Gated SPECT stress and stress-rest were done using either 1- or 2-day protocol as appropriate and Regadenoson was used as a stressing agent. Gated end systolic and diastolic left ventricular volumes were used to calculate ejection fraction. Perfusion was graded on a 5-point scale in all segments and summed stress score, summed rest score and summed difference score were assessed. [13] Scar was defined as summed rest score $>0$, ischemia as summed difference score $>0$ and significant ischemia as summed difference score>7. All studies were interpreted by experienced imaging cardiologists (all with greater than 10 years of experience.)

\section{Follow-Up and Outcomes}

The primary outcome was major adverse cardiovascular events (MACE - composite of all-cause death, MI and unplanned revascularization - PCI or CABG occurring more than 90 days after index imaging.) Myocardial infarction was defined as the $4^{\text {th }}$ universal definition of myocardial infarction. [14] All patients were followed from the date of the first imaging study. Patients were censored at either the occurrence of outcomes or the last known date of contact with the healthcare system as noted on the patient records.

\section{Statistical Analysis}

Continuous variables were presented as mean with standard deviation and categorical variables were presented as number with percent and compared using Student t test or chi-square test respectively.

Time-to-event was analyzed using Kaplan-Meier survival curves and compared using log-rank testing. Multivariable Cox regression models were used to determine the added prognostic role of SIS to an anatomic assessment using CCTA and functional assessment using SPECT MPI. Several nested models were assessed to determine incremental prediction, discrimination and risk-stratification. Models were compared using global chi-square, Akaike information criterion (AIC) and Harrel's C-statistic. Risk was predicted at 5 years of follow-up and risk reclassification was assessed using net reclassification index (NRI) on a continuous scale and categorical scale using annualized event rate thresholds of $<1 \%, 1-3 \%$ and $>3 \% / y e a r$. [15] The discrimination of variables when added to models was determined using integrated discrimination index (IDI.) Sensitivity analysis was done using several definitions of CCTA obstructive stenosis ( $\geq 50 \%$ on major vessels, $\geq 50 \%$ on major vessels or side branches) and SIS by plaque calcification (calcified SIS, mixed SIS, non-calcified SIS.)

All analyses were done after checking assumptions of linearity, collinearity and proportionality. Models were adjusted for predefined sociodemographic variables (age, gender), cardiovascular risk factors (hypertension, diabetes, dyslipidemia, ever smoking) symptoms of chest pain or shortness of breath, and early revascularization (PCl or CABG within 90 days of imaging.) All analyses were done using Stata 16.0 (StataCorp, College Station, Texas) and a pvalue of 0.05 was considered statistically significant.

\section{Results}

Our study population consisted of 956 patients. The median number of days between SPECT and CCTA was 15 (IQR: 2-101) and 60\% of patients had imaging within 30 days. Over three-fourth of the cohort had CCTA on the same day or after as SPECT (200 CT then SPECT vs 756 SPECT then CT.) 


\section{Baseline Characteristics}

Table 1 summarizes baseline characteristics of the study population. The mean (SD) age was $61.1 \pm 14.2$ years and $54.1 \%$ were men. The majority had clinical cardiovascular risk factors: $89 \%$ hypertension, $81 \%$ diabetes and $84 \%$ dyslipidemia. Most patients (56\%) were symptomatic with chest pain or shortness of breath and $80 \%$ were on aspirin or clopidogrel.

\section{Imaging}

Figure 1 shows an imaging example of a 73-year-old female patient with multiple cardiovascular risk factors, high SIS and non-obstructive stenosis on CCTA and no ischemia on SPECT. Obstructive stenosis ( $\geq 50 \%$ on left main / $\geq 70 \%$ stenosis on any other major segment) on CCTA and any ischemic defect on SPECT was present in $14 \%$ of patients. The mean (SD) SIS was $4.2( \pm 4.2)$. The total proportion of patients with ischemia by SPECT and SIS increased across increasing categories of CAD-RAD stenosis (Figure 2).

\section{Follow-up}

Table 2 summarizes characteristics of patients by the primary outcome. After a median follow up of 31 months (IQR: 12-65 months), 102 patients (10.7\%) experienced the primary outcome. Incidence rates were higher in those with vs without CCTA obstructive stenosis and any ischemia by SPECT (69 vs 23 ; 70 vs 23 events per 1000 person-year, respectively.) All-cause mortality accounted for over half of incident events (54\%, n=55), and late revascularization accounted for a quarter (19 PCl and $8 \mathrm{CABG}$ ). Patients with MACE were more likely to be older, more often male and had multiple comorbidities. Furthermore, they were more likely to have higher prevalence of obstructive coronary stenosis, higher CAD disease burden, higher prevalence of any myocardial ischemia on SPECT, and lower left ventricular ejection fraction on SPECT.

\section{Sequence of Imaging Studies}

Supplemental Table 1 compares characteristics of patients by sequence of CCTA or SPECT testing. Patients in either group had comparable rates of comorbidities and symptoms. Those that had SPECT after CCTA $(n=200)$ had higher rates of medication use, CCTA obstructive disease and atherosclerotic disease burden. Despite this, both groups had comparable rates of the primary outcome outcomes (31 vs 29 events per 1000 person-years, $p=0.77$ for CCTA followed by SPECT vs SPECT followed by CCTA respectively.)

\section{Outcomes}

Kaplan-Meier survival curves are shown in Figure 3. Both SPECT and CCTA showed high event rates with early separation of the event curves when stratified by SIS.

Table 3 and Supplementary table 2 summarize findings of the multivariable-adjusted Cox models. After adjusting for baseline variables, CCTA obstructive stenosis and ischemia by SPECT significantly predicted outcome alone (HR 2.24, 95\% Cl 1.44 - 3.49, p<0.001; 2.76, 95\% Cl $11.80-4.24, p<0.001$ respectively.) SIS was significantly associated with incident MACE and significantly improved discrimination when added to the model with CCTA obstructive stenosis (HR 1.15, 95\% Cl 1.09 - 1.21, <0.001; Harrel's C 0.74, p=0.008) and SPECT ischemia (HR 1.14, $95 \%$ Cl 1.08 - 1.20, p<0.001; Harrel's C $0.76, p=0.019)$. Furthermore, models with SIS had significantly higher global chi-square, integrated discrimination index (IDI) and correctly reclassified patients to appropriate risk categories on a continuous scale. Similar results were observed in a model with both CCTA obstructive stenosis and SPECT ischemia (HR 1.14, 95\% Cl 1.07 - 1.19, p<0.001) (supplementary table 2). Comparison of all models using AIC showed the model with SPECT and SIS to be the best compared to others in predicting the primary outcome.

Supplementary tables 3.1 and 3.2 summarize findings of sensitivity analysis using SIS by degree of plaque calcification. Summed scores of plaques with some degree of calcification (calcified, mixed and calcified/mixed SIS) significantly predicted incident outcomes. However, results similar to those of SIS model discrimination were not seen. Supplementary table 4 summarizes findings of sensitivity analysis using different thresholds of CCTA stenosis. SIS remained significantly associated with cardiovascular outcomes and improve model risk discrimination even with less stringent definitions of CCTA stenosis.

\section{Discussion}

In this study of 956 high risk patients with suspected CAD who underwent CCTA and SPECT imaging, SIS incrementally improved discrimination and appropriate risk stratification compared to traditional anatomic and functional measures. Results were consistent across several alternate definitions of obstructive stenosis and SIS by plaque composition.

Pre-test probability scores are the basis on which imaging tests are used in the diagnosis of patients with suspected CAD. [1] Those at low-intermediate risk commonly are recommended to undergo CCTA, while MPI (such as SPECT) is recommended for those at the higher end of the risk-spectrum. Current practice relies on presence of obstructive stenosis on CCTA or perfusion defect on SPECT to identify low vs high-risk patients. Although this does provide information beyond that of clinical scores, risk-stratification solely based on single variables is an oversimplification of the pathophysiology of CAD. This is evident by the discordance between either presence of stenosis or ischemia with cardiovascular outcomes, with some studies showing that as much as two-thirds of patients experiencing acute cardiovascular events have non-obstructive or non-ischemic lesions by CCTA or SPECT respectively. [3,16] Thus, current practice provides limited granularity on risk prediction necessary to individualize treatment in patients with suspected CAD. 
Considering this, several studies have investigated measures to further risk-stratify patients and guide management. Atherosclerotic disease burden is one such measure that is increasingly becoming an important prognostic indicator. Studies on coronary artery calcium scores (CACS), a simple and increasingly popular measure of CAD burden, have shown how patients can be placed on a continuum of risk and appropriate treatment based on the extent of calcifications. [17] More recent studies have also shown how patients with the same CACS have similar risk irrespective of presence of stenosis or of high-risk plaque features.[8,18]

This study is not the first to assess the prognostic role of SIS in patients with suspected CAD. A meta-analysis by Ayoub et al showed SIS score was prognostically comparable to more traditional CCTA measures such as presence of obstructive CAD. [19] Furthermore, several studies have established the role of SIS in subgroups of age, sex, non-obstructive disease and in those with any detectable coronary calcium.[20-24]

Our study builds on published literature by showing how SIS incrementally adds to established risk-stratifying tests. To our knowledge, no prior studies have evaluated the incremental prognostic role of SIS over SPECT MPI. However, our results agree with prior studies on CCTA. Nadjiri et al found SIS was significantly associated with MACE and incrementally added to multivariable models with Morise score and CAC. [25] A more recent analysis on 22,211 patients from the CONFIRM (Coronary CT Angiography EvaluatioN For Clinical Outcomes: An InteRnational Multicentre) registry similarly found age adjusted SIS significantly predicted outcomes and incrementally added discrimination and risk-reclassification to models with clinical predictors and obstructive CAD. [26]

Our findings contrast with a recent analysis from the SCOT-HEART trial in which low-attenuation, but not total plaque burden was significantly associated with the primary endpoint of fatal or non-fatal myocardial infarction. [27] One possible explanation for this discordance could be the difference in SIS scores by plaque calcification (median(IQR) calcific and non-calcific plaque 3(0-7) and 0(0-0) in our study vs 0.4(0-2.8) and 4.2(0-6.9) in SCOT-HEART respectively.)

\section{Plaque composition}

We also found that although the presence of calcified or mixed plaques were significantly associated with cardiovascular outcomes, the same was not found with non-calcified plaques. This agrees with a meta-analysis that did not find a statistically significant pooled hazard ratio using studies reporting non-calcific plaques. [19]

\section{CT vs SPECT}

Although not the primary aim of the current analysis, our findings have also shown how SPECT MPI together with SIS provides the best prognostic model in our cohort of high-risk patients. This agrees with prior studies and current European society of cardiology guidelines for the evaluation of patients with suspected CAD that have shown the superiority of functional techniques over anatomic methods for the diagnosis of ischemia at both patient and vessel level. [28] This stems from the fact that there is a discordance between angiographic stenosis and subsequent ischemia on both CCTA and invasive angiography, with fewer than half of angiographically obstructed lesions demonstrating ischemia. [29,30] [31] However, our data takes this further and shows that the inclusion of measures of plaque burden adds incremental prognostic value over perfusion imaging, even in this high-risk cohort.

\section{Clinical Implications}

Our findings add to prior studies showing the importance of atherosclerotic disease burden in the prognosis of patients with CAD. This supports the notion that SIS should be part of standard reporting in CCTA imaging, and consideration should be made to complimenting myocardial perfusion imaging with tests for burden of disease, like coronary artery calcium scoring. Ultimately, measures of CAD burden should be a routine component of diagnosing and tailoring management.

\section{Strengths}

We examined a real-world cohort of patients increasing the generalizability of our findings to those presenting to a tertiary care cardiology practice. We included patients with clinically indicated SPECT and CCTA tests, providing insight to a unique cohort of patients. Furthermore, several sensitivity analyses and the broad set of clinical variables models were adjusted for strengthens the robustness of our results.

\section{Limitations}

Our study is not without limitation. This is an observational single center study in a tertiary care setting, limiting generalizability. Furthermore, our cohort included patients who had undergone both CCTA and SPECT leading to selection bias in our analysis. We used chart review to determine baseline characteristics, potentially resulting in under-detection of clinical variables. However, both data collectors received extensive training and supervision throughout the collection process. Furthermore, quality checks were done by experienced cardiologists to determine clinical concordance of collected data. We did not make a distinction on medication use before vs after imaging. Certain exclusion criteria, such as those with revascularization between the two tests, limits the generalizability of our findings. However, inclusion of such patients would have introduced bias in the generalizability of our findings. We did not assess for high risk features on CCTA such as low-attenuation plaques, spotty calcifications, positive remodeling or a napkin ring sign. However, recent studies have found that such features did not independently predict incident events when considering the burden of disease. [8] Although we checked for collinearity between burden of disease and presence of obstruction on CCTA, we can't completely rule out this possibility. However, similar findings from other studies such as those from Mortensen et al makes this an unlikely scenario. [18] Lastly, no independent committee adjudicated incident events, which may have limited accuracy. 


\section{Conclusion}

In this large, high-risk, mixed cohort of patients undergoing clinically indicated CCTA and SPECT for suspected CAD, burden of atherosclerotic plaque as evaluated by CCTA has incremental value in risk stratification over and above traditional CCTA and SPECT measures.

\section{Abbreviations}

CCTA - Coronary computed tomography angiography

MPI - Myocardial perfusion imaging

SIS - Segment involvement score

SPECT - Single photon emission computed tomography

\section{Declarations}

Funding: No funds, grants, or other support was received for conducting this study.

Conflicts of interest/Competing interests: Dr Mouaz Al-Mallah receives research support from Siemens unrelated to this study. All other authors certify that they have no affiliations with or involvement in any organization or entity with any financial interest or non-financial interest in the subject matter or materials discussed in this manuscript.

Availability of data and material: The datasets generated during and/or analyzed during the current study are not publicly available as they content patient health information.

Code availability: Not available.

Ethics approval: This retrospective chart review study involving human participants was in accordance with the 1964 Helsinki Declaration and its later amendments or comparable ethical standards. Approval from the Institutional Review Board at the Houston Methodist Academic Institute was obtained prior to the start of the study.

Consent to participate: Informed consent was waived due to the retrospective nature of the study.

Consent for publication: Not applicable.

\section{References}

1. Knuuti J, Wijns W, Saraste A, et al. 2019 ESC guidelines for the diagnosis and management of chronic coronary syndromes: The task force for the diagnosis and management of chronic coronary syndromes of the european society of cardiology (ESC). Eur Heart J. 2020;41(3):407-477.

2. Carità P, Guaricci Al, Muscogiuri G, Carrabba N, Pontone G. Prognostic value and therapeutic perspectives of coronary CT angiography: A literature review. Biomed Res Int. 2018;2018:6528238.

3. Newby DE, Adamson PD, Berry C, et al. Coronary CT angiography and 5-year risk of myocardial infarction. N Eng/ J Med. 2018;379(10):924-933.

4. Karády J, Mayrhofer T, Ivanov A, et al. Cost-effectiveness analysis of anatomic vs functional index testing in patients with low-risk stable chest pain. JAMA Netw Open. 2020;3(12):e2028312.

5. Shaw LJ, Iskandrian AE. Prognostic value of gated myocardial perfusion SPECT. J Nucl Cardiol. 2004;11(2):171-185.

6. Al Badarin FJ, Malhotra S. Diagnosis and prognosis of coronary artery disease with SPECT and PET. Curr Cardiol Rep. 2019;21(7):57.

7. Arbab-Zadeh A, Fuster V. The risk continuum of atherosclerosis and its implications for defining CHD by Coronary angiography. J Am Coll Cardiol. 2016;68(22):2467-2478.

8. Williams MC, Moss AJ, Dweck M, et al. Coronary artery plaque characteristics associated with adverse outcomes in the SCOT-HEART study. $J$ Am Coll Cardiol. 2019;73(3):291-301.

9. Abbara S, Blanke P, Maroules CD, et al. SCCT guidelines for the performance and acquisition of coronary computed tomographic angiography: A report of the society of cardiovascular computed tomography guidelines committee: Endorsed by the north american society for cardiovascular imaging (NASCI). $J$ Cardiovasc Comput Tomogr. 2016;10(6):435-449.

10. Abbara S, Blanke P, Maroules CD, et al. SCCT guidelines for the performance and acquisition of coronary computed tomographic angiography: A report of the society of cardiovascular computed tomography guidelines committee: Endorsed by the north american society for cardiovascular imaging (NASCI). J Cardiovasc Comput Tomogr. 2016;10(6):435-449. 
11. Cury RC, Abbara S, Achenbach S, et al. Coronary artery disease - reporting and Data System (CAD-RADS): An expert consensus document of SCCT, ACR and NASCl: Endorsed by the ACC. JACC Cardiovasc Imaging. 2016;9(9):1099-1113.

12. Dorbala S, Ananthasubramaniam K, Armstrong IS, et al. Single photon emission computed tomography (SPECT) myocardial perfusion imaging guidelines: Instrumentation, acquisition, processing, and interpretation. J Nucl Cardiol. 2018;25(5):1784-1846.

13. Holly TA, Abbott BG, Al-Mallah M, et al. Single photon-emission computed tomography. Journal of nuclear cardiology. 2010;17(5):941-973.

14. Thygesen K, Alpert JS, Jaffe AS, et al. Fourth universal definition of myocardial infarction (2018). J Am Coll Cardiol. 2018;72(18):2231-2264.

15. Fihn SD, Blankenship JC, Alexander KP, et al. 2014 ACC/AHA/AATS/PCNA/SCAI/STS focused update of the guideline for the diagnosis and management of patients with stable ischemic heart disease: A report of the american college of cardiology/american heart association task force on practice guidelines, and the american association for thoracic surgery, preventive cardiovascular nurses association, society for cardiovascular angiography and interventions, and society of thoracic surgeons. J Am Coll Cardiol. 2014;64(18):1929-1949.

16. Hoffmann U, Ferencik M, Udelson JE, et al. Prognostic value of noninvasive cardiovascular testing in patients with stable chest pain: Insights from the PROMISE trial (prospective multicenter imaging study for evaluation of chest pain). Circulation. 2017;135(24):2320-2332.

17. Lo-Kioeng-Shioe MS, Rijlaarsdam-Hermsen D, van Domburg RT, et al. Prognostic value of coronary artery calcium score in symptomatic individuals: A meta-analysis of 34,000 subjects. Int J Cardiol. 2020;299:56-62.

18. Mortensen MB, Dzaye O, Steffensen $\mathrm{FH}$, et al. Impact of plaque burden versus stenosis on ischemic events in patients with coronary atherosclerosis. $J$ Am Coll Cardiol. 2020;76(24):2803-2813.

19. Ayoub C, Erthal F, Abdelsalam MA, et al. Prognostic value of segment involvement score compared to other measures of coronary atherosclerosis by computed tomography: A systematic review and meta-analysis. J Cardiovasc Comput Tomogr. 2017;11(4):258-267.

20. Schulman-Marcus J, Hartaigh BÓ, Gransar H, et al. Sex-specific associations between coronary artery plaque extent and risk of Major adverse cardiovascular events: The CONFIRM long-term registry. JACC Cardiovasc Imaging. 2016;9(4):364-372.

21. Bittencourt MS, Hulten E, Ghoshhajra B, et al. Prognostic value of nonobstructive and obstructive coronary artery disease detected by coronary computed tomography angiography to identify cardiovascular events. Circ Cardiovasc Imaging. 2014;7(2):282-291.

22. Al-Mallah MH, Qureshi W, Lin FY, et al. Does coronary CT angiography improve risk stratification over coronary calcium scoring in symptomatic patients with suspected coronary artery disease? results from the prospective multicenter international CONFIRM registry. Eur Heart $J$ Cardiovasc Imaging. 2014;15(3):267-274.

23. Naoum C, Berman DS, Ahmadi A, et al. Predictive value of age- and sex-specific nomograms of global plaque burden on coronary computed tomography angiography for major cardiac events. Circ Cardiovasc Imaging. 2017;10(3).

24. van Rosendael AR, Bax AM, Smit JM, et al. Clinical risk factors and atherosclerotic plaque extent to define risk for major events in patients without obstructive coronary artery disease: The long-term coronary computed tomography angiography CONFIRM registry. Eur Heart J Cardiovasc Imaging. 2020;21(5):479-488.

25. Nadjiri J, Hausleiter J, Jähnichen C, et al. Incremental prognostic value of quantitative plaque assessment in coronary CT angiography during 5 years of follow up. J Cardiovasc Comput Tomogr. 2016;10(2):97-104.

26. Ayoub C, Kritharides L, Yam Y, et al. Prognostic value of age adjusted segment involvement score as measured by coronary computed tomography: A potential marker of vascular age. Heart Vessels. 2018;33(11):1288-1300.

27. Williams MC, Kwiecinski J, Doris M, et al. Low-attenuation noncalcified plaque on coronary computed tomography angiography predicts myocardial infarction: Results from the multicenter SCOT-HEART trial (scottish computed tomography of the HEART). Circulation. 2020;141(18):1452-1462.

28. Danad I, Szymonifka J, Twisk JWR, et al. Diagnostic performance of cardiac imaging methods to diagnose ischaemia-causing coronary artery disease when directly compared with fractional flow reserve as a reference standard: A meta-analysis. Eur Heart J. 2017;38(13):991-998.

29. Tonino PAL, De Bruyne B, Pijls NHJ, et al. Fractional flow reserve versus angiography for guiding percutaneous coronary intervention. New England Journal of Medicine. 2009;360(3):213-224.

30. Meijboom WB, Van Mieghem, Carlos A. G., van Pelt N, et al. Comprehensive assessment of coronary artery stenoses: Computed tomography coronary angiography versus conventional coronary angiography and correlation with fractional flow reserve in patients with stable angina. $J$ Am Coll Cardiol. 2008;52(8):636-643.

31. Foy AJ, Dhruva SS, Peterson B, Mandrola JM, Morgan DJ, Redberg RF. Coronary computed tomography angiography vs functional stress testing for patients with suspected coronary artery disease: A systematic review and meta-analysis. JAMA Intern Med. 2017;177(11):1623-1631.

Page $7 / 14$ 
Tables

Page $8 / 14$ 


\begin{tabular}{|c|c|c|c|c|c|c|c|c|c|c|}
\hline \multirow[b]{2}{*}{ Sociodemographic } & \multirow[t]{2}{*}{ Total } & \multicolumn{3}{|c|}{ CCTA Obstructive Stenosis } & \multicolumn{3}{|c|}{ SPECT - Ischemia } & \multicolumn{3}{|c|}{ CCTA SIS >3 } \\
\hline & & No & Yes & $P$ & No & Yes & $P$ & No & Yes & $P$ \\
\hline & $N=956$ & $N=818$ & $N=138$ & & $N=818$ & $N=138$ & & $N=500$ & $N=456$ & \\
\hline Age - Mean(SD) & $\begin{array}{l}61.14 \\
(14.20)\end{array}$ & $\begin{array}{l}59.97 \\
(14.21)\end{array}$ & $\begin{array}{l}68.04 \\
(12.05)\end{array}$ & $<0.001$ & $\begin{array}{l}61.02 \\
(14.26)\end{array}$ & $\begin{array}{l}61.84 \\
(13.87)\end{array}$ & 0.53 & $\begin{array}{l}55.71 \\
(13.87)\end{array}$ & $\begin{array}{l}67.09 \\
(12.01)\end{array}$ & $<0.001$ \\
\hline Gender - N(\%) & & & & 0.055 & & & 0.084 & & & $<0.001$ \\
\hline Female & $\begin{array}{l}439 \\
(45.9 \%)\end{array}$ & $\begin{array}{l}386 \\
(47.2 \%)\end{array}$ & $\begin{array}{l}53 \\
(38.4 \%)\end{array}$ & & $\begin{array}{l}385 \\
(47.1 \%)\end{array}$ & $\begin{array}{l}54 \\
(39.1 \%)\end{array}$ & & $\begin{array}{l}263 \\
(52.6 \%)\end{array}$ & $\begin{array}{l}176 \\
(38.6 \%)\end{array}$ & \\
\hline \multicolumn{11}{|l|}{ Comorbidities } \\
\hline Hypertension - N(\%) & $\begin{array}{l}848 \\
(88.7 \%)\end{array}$ & $\begin{array}{l}719 \\
(87.9 \%)\end{array}$ & $\begin{array}{l}129 \\
(93.5 \%)\end{array}$ & 0.055 & $\begin{array}{l}720 \\
(88.0 \%)\end{array}$ & $\begin{array}{l}128 \\
(92.8 \%)\end{array}$ & 0.10 & $\begin{array}{l}426 \\
(85.2 \%)\end{array}$ & $\begin{array}{l}422 \\
(92.5 \%)\end{array}$ & $<0.001$ \\
\hline Diabetes - N(\%) & $\begin{array}{l}778 \\
(81.4 \%)\end{array}$ & $\begin{array}{l}659 \\
(80.6 \%)\end{array}$ & $\begin{array}{l}119 \\
(86.2 \%)\end{array}$ & 0.11 & $\begin{array}{l}657 \\
(80.3 \%)\end{array}$ & $\begin{array}{l}121 \\
(87.7 \%)\end{array}$ & 0.040 & $\begin{array}{l}397 \\
(79.4 \%)\end{array}$ & $\begin{array}{l}381 \\
(83.6 \%)\end{array}$ & 0.099 \\
\hline Dyslipidemia - N(\%) & $\begin{array}{l}806 \\
(84.3 \%)\end{array}$ & $\begin{array}{l}674 \\
(82.4 \%)\end{array}$ & $\begin{array}{l}132 \\
(95.7 \%)\end{array}$ & $<0.001$ & $\begin{array}{l}680 \\
(83.1 \%)\end{array}$ & $\begin{array}{l}126 \\
(91.3 \%)\end{array}$ & 0.015 & $\begin{array}{l}382 \\
(76.4 \%)\end{array}$ & $\begin{array}{l}424 \\
(93.0 \%)\end{array}$ & $<0.001$ \\
\hline Heart Failure - N(\%) & $\begin{array}{l}107 \\
(11.2 \%)\end{array}$ & $\begin{array}{l}86 \\
(10.5 \%)\end{array}$ & $\begin{array}{l}21 \\
(15.2 \%)\end{array}$ & 0.10 & $\begin{array}{l}85 \\
(10.4 \%)\end{array}$ & $\begin{array}{l}22 \\
(15.9 \%)\end{array}$ & 0.056 & $\begin{array}{l}49 \\
(9.8 \%)\end{array}$ & $\begin{array}{l}58 \\
(12.7 \%)\end{array}$ & 0.15 \\
\hline Ever Smoker - N(\%) & $\begin{array}{l}317 \\
(33.2 \%)\end{array}$ & $\begin{array}{l}257 \\
(31.4 \%)\end{array}$ & $\begin{array}{l}60 \\
(43.5 \%)\end{array}$ & 0.005 & $\begin{array}{l}263 \\
(32.2 \%)\end{array}$ & $\begin{array}{l}54 \\
(39.1 \%)\end{array}$ & 0.11 & $\begin{array}{l}144 \\
(28.8 \%)\end{array}$ & $\begin{array}{l}173 \\
(37.9 \%)\end{array}$ & 0.003 \\
\hline \multicolumn{11}{|l|}{ Symptoms } \\
\hline $\begin{array}{l}\text { Chest Pain or Shortness of Breath - } \\
\mathrm{N}(\%)\end{array}$ & $\begin{array}{l}537 \\
(56.2 \%)\end{array}$ & $\begin{array}{l}474 \\
(57.9 \%)\end{array}$ & $\begin{array}{l}63 \\
(45.7 \%)\end{array}$ & 0.007 & $\begin{array}{l}472 \\
(57.7 \%)\end{array}$ & $\begin{array}{l}65 \\
(47.1 \%)\end{array}$ & 0.020 & $\begin{array}{l}306 \\
(61.2 \%)\end{array}$ & $\begin{array}{l}231 \\
(50.7 \%)\end{array}$ & 0.001 \\
\hline \multicolumn{11}{|l|}{ Medication } \\
\hline Aspirin/Clopidogrel - N(\%) & $\begin{array}{l}768 \\
(80.3 \%)\end{array}$ & $\begin{array}{l}645 \\
(78.9 \%)\end{array}$ & $\begin{array}{l}123 \\
(89.1 \%)\end{array}$ & 0.005 & $\begin{array}{l}647 \\
(79.1 \%)\end{array}$ & $\begin{array}{l}121 \\
(87.7 \%)\end{array}$ & 0.019 & $\begin{array}{l}377 \\
(75.4 \%)\end{array}$ & $\begin{array}{l}391 \\
(85.7 \%)\end{array}$ & $<0.001$ \\
\hline Statin - N(\%) & $\begin{array}{l}706 \\
(73.8 \%)\end{array}$ & $\begin{array}{l}582 \\
(71.1 \%)\end{array}$ & $\begin{array}{l}124 \\
(89.9 \%)\end{array}$ & $<0.001$ & $\begin{array}{l}589 \\
(72.0 \%)\end{array}$ & $\begin{array}{l}117 \\
(84.8 \%)\end{array}$ & 0.002 & $\begin{array}{l}316 \\
(63.2 \%)\end{array}$ & $\begin{array}{l}390 \\
(85.5 \%)\end{array}$ & $<0.001$ \\
\hline ACE/ARB - N(\%) & $\begin{array}{l}625 \\
(65.4 \%)\end{array}$ & $\begin{array}{l}525 \\
(64.2 \%)\end{array}$ & $\begin{array}{l}100 \\
(72.5 \%)\end{array}$ & 0.059 & $\begin{array}{l}527 \\
(64.4 \%)\end{array}$ & $\begin{array}{l}98 \\
(71.0 \%)\end{array}$ & 0.13 & $\begin{array}{l}293 \\
(58.6 \%)\end{array}$ & $\begin{array}{l}332 \\
(72.8 \%)\end{array}$ & $<0.001$ \\
\hline Beta Blockers - N(\%) & $\begin{array}{l}770 \\
(80.5 \%)\end{array}$ & $\begin{array}{l}654 \\
(80.0 \%)\end{array}$ & $\begin{array}{l}116 \\
(84.1 \%)\end{array}$ & 0.26 & $\begin{array}{l}645 \\
(78.9 \%)\end{array}$ & $\begin{array}{l}125 \\
(90.6 \%)\end{array}$ & 0.001 & $\begin{array}{l}389 \\
(77.8 \%)\end{array}$ & $\begin{array}{l}381 \\
(83.6 \%)\end{array}$ & 0.025 \\
\hline Calcium Channel Blockers - N(\%) & $\begin{array}{l}431 \\
(45.1 \%)\end{array}$ & $\begin{array}{l}359 \\
(43.9 \%)\end{array}$ & $\begin{array}{l}72 \\
(52.2 \%)\end{array}$ & 0.070 & $\begin{array}{l}369 \\
(45.1 \%)\end{array}$ & $\begin{array}{l}62 \\
(44.9 \%)\end{array}$ & 0.97 & $\begin{array}{l}193 \\
(38.6 \%)\end{array}$ & $\begin{array}{l}238 \\
(52.2 \%)\end{array}$ & $<0.001$ \\
\hline \multicolumn{11}{|l|}{ CCTA Stenosis } \\
\hline CCTA CAD-RAD - N(\%) & & & & $<0.001$ & & & $<0.001$ & & & $<0.001$ \\
\hline CAD RAD 0 & $\begin{array}{l}288 \\
(30.1 \%)\end{array}$ & $\begin{array}{l}288 \\
(35.2 \%)\end{array}$ & $0(0.0 \%)$ & & $\begin{array}{l}262 \\
(32.0 \%)\end{array}$ & $\begin{array}{l}26 \\
(18.8 \%)\end{array}$ & & $\begin{array}{l}288 \\
(57.6 \%)\end{array}$ & $\begin{array}{l}0 \\
(0.0 \%)\end{array}$ & \\
\hline CAD RAD $1 / 2$ & $\begin{array}{l}375 \\
(39.2 \%)\end{array}$ & $\begin{array}{l}375 \\
(45.8 \%)\end{array}$ & $0(0.0 \%)$ & & $\begin{array}{l}340 \\
(41.6 \%)\end{array}$ & $\begin{array}{l}35 \\
(25.4 \%)\end{array}$ & & $\begin{array}{l}173 \\
(34.6 \%)\end{array}$ & $\begin{array}{l}202 \\
(44.3 \%)\end{array}$ & \\
\hline CAD RAD 3 & $\begin{array}{l}135 \\
(14.1 \%)\end{array}$ & $\begin{array}{l}135 \\
(16.5 \%)\end{array}$ & $0(0.0 \%)$ & & $\begin{array}{l}117 \\
(14.3 \%)\end{array}$ & $\begin{array}{l}18 \\
(13.0 \%)\end{array}$ & & $\begin{array}{l}28 \\
(5.6 \%)\end{array}$ & $\begin{array}{l}107 \\
(23.5 \%)\end{array}$ & \\
\hline CAD RAD 4A & $\begin{array}{l}97 \\
(10.1 \%)\end{array}$ & $\begin{array}{l}19 \\
(2.3 \%)\end{array}$ & $\begin{array}{l}78 \\
(56.5 \%)\end{array}$ & & $\begin{array}{l}68 \\
(8.3 \%)\end{array}$ & $\begin{array}{l}29 \\
(21.0 \%)\end{array}$ & & $\begin{array}{l}9 \\
(1.8 \%)\end{array}$ & $\begin{array}{l}88 \\
(19.3 \%)\end{array}$ & \\
\hline CAD RAD 4B & $\begin{array}{l}61 \\
(6.4 \%)\end{array}$ & $1(0.1 \%)$ & $\begin{array}{l}60 \\
(43.5 \%)\end{array}$ & & $\begin{array}{l}31 \\
(3.8 \%)\end{array}$ & $\begin{array}{l}30 \\
(21.7 \%)\end{array}$ & & $\begin{array}{l}2 \\
(0.4 \%)\end{array}$ & $\begin{array}{l}59 \\
(12.9 \%)\end{array}$ & \\
\hline $\begin{array}{l}\text { CCTA stenosis }>70 \% \text { on any segment - } \\
\mathrm{N}(\%)\end{array}$ & $\begin{array}{l}150 \\
(15.7 \%)\end{array}$ & $\begin{array}{l}20 \\
(2.4 \%)\end{array}$ & $\begin{array}{l}130 \\
(94.2 \%)\end{array}$ & $<0.001$ & $\begin{array}{l}93 \\
(11.4 \%)\end{array}$ & $\begin{array}{l}57 \\
(41.3 \%)\end{array}$ & $<0.001$ & $\begin{array}{l}11 \\
(2.2 \%)\end{array}$ & $\begin{array}{l}139 \\
(30.5 \%)\end{array}$ & $<0.001$ \\
\hline $\begin{array}{l}\text { CCTA stenosis }>70 \% \text { on any } \\
\text { proximal } / \mathrm{mid} / \text { distal segment }-\mathrm{N}(\%)\end{array}$ & $\begin{array}{l}128 \\
(13.4 \%)\end{array}$ & $0(0.0 \%)$ & $\begin{array}{l}128 \\
(92.8 \%)\end{array}$ & $<0.001$ & $\begin{array}{l}77 \\
(9.4 \%)\end{array}$ & $\begin{array}{l}51 \\
(37.0 \%)\end{array}$ & $<0.001$ & $\begin{array}{l}7 \\
(1.4 \%)\end{array}$ & $\begin{array}{l}121 \\
(26.5 \%)\end{array}$ & $<0.001$ \\
\hline $\begin{array}{l}\text { CCTA stenosis }>50 \% \text { on any segment - } \\
\mathrm{N}(\%)\end{array}$ & $\begin{array}{l}293 \\
(30.6 \%)\end{array}$ & $\begin{array}{l}155 \\
(18.9 \%)\end{array}$ & $\begin{array}{l}138 \\
(100.0 \%)\end{array}$ & $<0.001$ & $\begin{array}{l}216 \\
(26.4 \%)\end{array}$ & $\begin{array}{l}77 \\
(55.8 \%)\end{array}$ & $<0.001$ & $\begin{array}{l}39 \\
(7.8 \%)\end{array}$ & $\begin{array}{l}254 \\
(55.7 \%)\end{array}$ & $<0.001$ \\
\hline $\begin{array}{l}\text { CCTA stenosis }>50 \% \text { on any } \\
\text { proximal/mid/distal segment }-\mathrm{N}(\%)\end{array}$ & $\begin{array}{l}269 \\
(28.1 \%)\end{array}$ & $\begin{array}{l}131 \\
(16.0 \%)\end{array}$ & $\begin{array}{l}138 \\
(100.0 \%)\end{array}$ & $<0.001$ & $\begin{array}{l}196 \\
(24.0 \%)\end{array}$ & $\begin{array}{l}73 \\
(52.9 \%)\end{array}$ & $<0.001$ & $\begin{array}{l}34 \\
(6.8 \%)\end{array}$ & $\begin{array}{l}235 \\
(51.5 \%)\end{array}$ & $<0.001$ \\
\hline
\end{tabular}


CCTA Burden of Disease

\begin{tabular}{|c|c|c|c|c|c|c|c|c|c|c|}
\hline $\begin{array}{l}\text { Segment Involvement Score (SIS) - } \\
\text { Mean(SD) }\end{array}$ & $\begin{array}{l}4.24 \\
(4.16)\end{array}$ & $\begin{array}{l}3.48 \\
(3.82)\end{array}$ & $\begin{array}{l}8.75 \\
(3.13)\end{array}$ & $<0.001$ & $\begin{array}{l}3.88 \\
(3.97)\end{array}$ & $\begin{array}{l}6.38 \\
(4.63)\end{array}$ & $<0.001$ & $\begin{array}{l}0.76 \\
(1.04)\end{array}$ & $\begin{array}{l}8.06 \\
(2.68)\end{array}$ & $<0.001$ \\
\hline $\begin{array}{l}\text { Calcified/Mixed Plaque Segment } \\
\text { Involvement Score - Mean(SD) }\end{array}$ & $\begin{array}{l}3.94 \\
(4.06)\end{array}$ & $\begin{array}{l}3.23 \\
(3.74)\end{array}$ & $\begin{array}{l}8.09 \\
(3.41)\end{array}$ & $<0.001$ & $\begin{array}{l}3.60 \\
(3.87)\end{array}$ & $\begin{array}{l}5.91 \\
(4.59)\end{array}$ & $<0.001$ & $\begin{array}{l}0.62 \\
(0.99)\end{array}$ & $\begin{array}{l}7.57 \\
(2.89)\end{array}$ & $<0.001$ \\
\hline $\begin{array}{l}\text { Calcified Plaque Segment Involvement } \\
\text { Score - Mean(SD) }\end{array}$ & $\begin{array}{l}1.48 \\
(2.65)\end{array}$ & $\begin{array}{l}1.30 \\
(2.46)\end{array}$ & $\begin{array}{l}2.55 \\
(3.36)\end{array}$ & $<0.001$ & $\begin{array}{l}1.36 \\
(2.52)\end{array}$ & $\begin{array}{l}2.17 \\
(3.25)\end{array}$ & $<0.001$ & $\begin{array}{l}0.23 \\
(0.61)\end{array}$ & $\begin{array}{l}2.85 \\
(3.27)\end{array}$ & $<0.001$ \\
\hline $\begin{array}{l}\text { Mixed Plaque Segment Involvement } \\
\text { Score-Mean(SD) }\end{array}$ & $\begin{array}{l}2.46 \\
(3.25)\end{array}$ & $\begin{array}{l}1.94 \\
(2.84)\end{array}$ & $\begin{array}{l}5.54 \\
(3.76)\end{array}$ & $<0.001$ & $\begin{array}{l}2.24 \\
(3.04)\end{array}$ & $\begin{array}{l}3.73 \\
(4.07)\end{array}$ & $<0.001$ & $\begin{array}{l}0.39 \\
(0.80)\end{array}$ & $\begin{array}{l}4.72 \\
(3.41)\end{array}$ & $<0.001$ \\
\hline $\begin{array}{l}\text { Non-Calcified Plaque Segment } \\
\text { Involvement Score - Mean(SD) }\end{array}$ & $\begin{array}{l}0.31 \\
(0.78)\end{array}$ & $\begin{array}{l}0.24 \\
(0.66)\end{array}$ & $\begin{array}{l}0.67 \\
(1.22)\end{array}$ & $<0.001$ & $\begin{array}{l}0.28 \\
(0.73)\end{array}$ & $\begin{array}{l}0.48 \\
(1.03)\end{array}$ & 0.005 & $\begin{array}{l}0.13 \\
(0.42)\end{array}$ & $\begin{array}{l}0.50 \\
(1.01)\end{array}$ & $<0.001$ \\
\hline \multicolumn{11}{|l|}{ SPECT } \\
\hline Any Ischemia - N(\%) & $\begin{array}{l}138 \\
(14.4 \%)\end{array}$ & $\begin{array}{l}85 \\
(10.4 \%)\end{array}$ & $\begin{array}{l}53 \\
(38.4 \%)\end{array}$ & $<0.001$ & $\begin{array}{l}0 \\
(0.0 \%)\end{array}$ & $\begin{array}{l}138 \\
(100.0 \%)\end{array}$ & $<0.001$ & $\begin{array}{l}46 \\
(9.2 \%)\end{array}$ & $\begin{array}{l}92 \\
(20.2 \%)\end{array}$ & $<0.001$ \\
\hline Significant Ischemia (>10\%) - N(\%) & $\begin{array}{l}39 \\
(4.1 \%)\end{array}$ & $\begin{array}{l}14 \\
(1.7 \%)\end{array}$ & $\begin{array}{l}25 \\
(18.1 \%)\end{array}$ & $<0.001$ & $\begin{array}{l}0 \\
(0.0 \%)\end{array}$ & $\begin{array}{l}39 \\
(28.3 \%)\end{array}$ & $<0.001$ & $\begin{array}{l}5 \\
(1.0 \%)\end{array}$ & $\begin{array}{l}34 \\
(7.5 \%)\end{array}$ & $<0.001$ \\
\hline Scar - N(\%) & $\begin{array}{l}158 \\
(16.5 \%)\end{array}$ & $\begin{array}{l}102 \\
(12.5 \%)\end{array}$ & $\begin{array}{l}56 \\
(40.6 \%)\end{array}$ & $<0.001$ & $\begin{array}{l}85 \\
(10.4 \%)\end{array}$ & $\begin{array}{l}73 \\
(52.9 \%)\end{array}$ & $<0.001$ & $\begin{array}{l}57 \\
(11.4 \%)\end{array}$ & $\begin{array}{l}101 \\
(22.1 \%)\end{array}$ & $<0.001$ \\
\hline LVEF - N(\%) & & & & 0.034 & & & $<0.001$ & & & 0.042 \\
\hline$<35 \%$ & $\begin{array}{l}61 \\
(6.4 \%)\end{array}$ & $\begin{array}{l}49 \\
(6.0 \%)\end{array}$ & $\begin{array}{l}12 \\
(8.7 \%)\end{array}$ & & $\begin{array}{l}46 \\
(5.6 \%)\end{array}$ & $\begin{array}{l}15 \\
(10.9 \%)\end{array}$ & & $\begin{array}{l}28 \\
(5.6 \%)\end{array}$ & $\begin{array}{l}33 \\
(7.2 \%)\end{array}$ & \\
\hline $35-50 \%$ & $\begin{array}{l}96 \\
(10.0 \%)\end{array}$ & $\begin{array}{l}75 \\
(9.2 \%)\end{array}$ & $\begin{array}{l}21 \\
(15.2 \%)\end{array}$ & & $\begin{array}{l}64 \\
(7.8 \%)\end{array}$ & $\begin{array}{l}32 \\
(23.2 \%)\end{array}$ & & $\begin{array}{l}40 \\
(8.0 \%)\end{array}$ & $\begin{array}{l}56 \\
(12.3 \%)\end{array}$ & \\
\hline$>50 \%$ & $\begin{array}{l}799 \\
(83.6 \%)\end{array}$ & $\begin{array}{l}694 \\
(84.8 \%)\end{array}$ & $\begin{array}{l}105 \\
(76.1 \%)\end{array}$ & & $\begin{array}{l}708 \\
(86.6 \%)\end{array}$ & $\begin{array}{l}91 \\
(65.9 \%)\end{array}$ & & $\begin{array}{l}432 \\
(86.4 \%)\end{array}$ & $\begin{array}{l}367 \\
(80.5 \%)\end{array}$ & \\
\hline
\end{tabular}

Outcomes

MACE

\begin{tabular}{|c|c|c|c|c|c|c|c|c|c|c|}
\hline $\begin{array}{l}\text { Incidence Rate (per } 1000 \text { person- } \\
\text { year) }\end{array}$ & 29.2 & 22.9 & 69 & $<0.001$ & 22.9 & 69 & $<0.001$ & 22.9 & 69 & $<0.001$ \\
\hline $\mathrm{N}(\%)$ & $\begin{array}{l}102 \\
(10.7 \%)\end{array}$ & $\begin{array}{l}69 \\
(8.4 \%)\end{array}$ & $\begin{array}{l}33 \\
(23.9 \%)\end{array}$ & $<0.001$ & $\begin{array}{l}69 \\
(8.4 \%)\end{array}$ & $\begin{array}{l}33 \\
(23.9 \%)\end{array}$ & $<0.001$ & $\begin{array}{l}31 \\
(6.2 \%)\end{array}$ & $\begin{array}{l}71 \\
(15.6 \%)\end{array}$ & $<0.001$ \\
\hline All-Cause Death - N(\%) & $\begin{array}{l}55 \\
(5.8 \%)\end{array}$ & $\begin{array}{l}41 \\
(5.0 \%)\end{array}$ & $\begin{array}{l}14 \\
(10.1 \%)\end{array}$ & 0.017 & $\begin{array}{l}38 \\
(4.6 \%)\end{array}$ & $\begin{array}{l}17 \\
(12.3 \%)\end{array}$ & $<0.001$ & $\begin{array}{l}19 \\
(3.8 \%)\end{array}$ & $\begin{array}{l}36 \\
(7.9 \%)\end{array}$ & 0.007 \\
\hline Myocardial Infarction - N(\%) & $\begin{array}{l}29 \\
(3.0 \%)\end{array}$ & $\begin{array}{l}19 \\
(2.3 \%)\end{array}$ & $\begin{array}{l}10 \\
(7.2 \%)\end{array}$ & 0.002 & $\begin{array}{l}19 \\
(2.3 \%)\end{array}$ & $\begin{array}{l}10 \\
(7.2 \%)\end{array}$ & 0.002 & $\begin{array}{l}6 \\
(1.2 \%)\end{array}$ & $\begin{array}{l}23 \\
(5.0 \%)\end{array}$ & $<0.001$ \\
\hline $\mathrm{PCl}$ 90-days post imaging - N(\%) & $\begin{array}{l}19 \\
(2.0 \%)\end{array}$ & $9(1.1 \%)$ & $\begin{array}{l}10 \\
(7.2 \%)\end{array}$ & $<0.001$ & $\begin{array}{l}12 \\
(1.5 \%)\end{array}$ & $7(5.1 \%)$ & 0.005 & $\begin{array}{l}5 \\
(1.0 \%)\end{array}$ & $\begin{array}{l}14 \\
(3.1 \%)\end{array}$ & 0.022 \\
\hline CABG 90-days post imaging - $\mathrm{N}(\%)$ & $8(0.8 \%)$ & $2(0.2 \%)$ & $6(4.3 \%)$ & $<0.001$ & $\begin{array}{l}4 \\
(0.5 \%)\end{array}$ & $4(2.9 \%)$ & 0.004 & $\begin{array}{l}1 \\
(0.2 \%)\end{array}$ & $\begin{array}{l}7 \\
(1.5 \%)\end{array}$ & 0.024 \\
\hline
\end{tabular}

$A C E$ - angiotensin converting enzyme inhibitors, $A R B$ - angiotensin receptor blockers, CABG - coronary artery bypass graft, CAD-RAD - cardiology coronary artery disease reporting \& data System, CCTA - coronary CT angiography, CT - computed tomography, LVEF-left ventricular ejection fraction,

MACE - major adverse cardiovascular outcomes, $P C l$ - percutaneous coronary intervention, SPECT - single photon emission computed tomography 


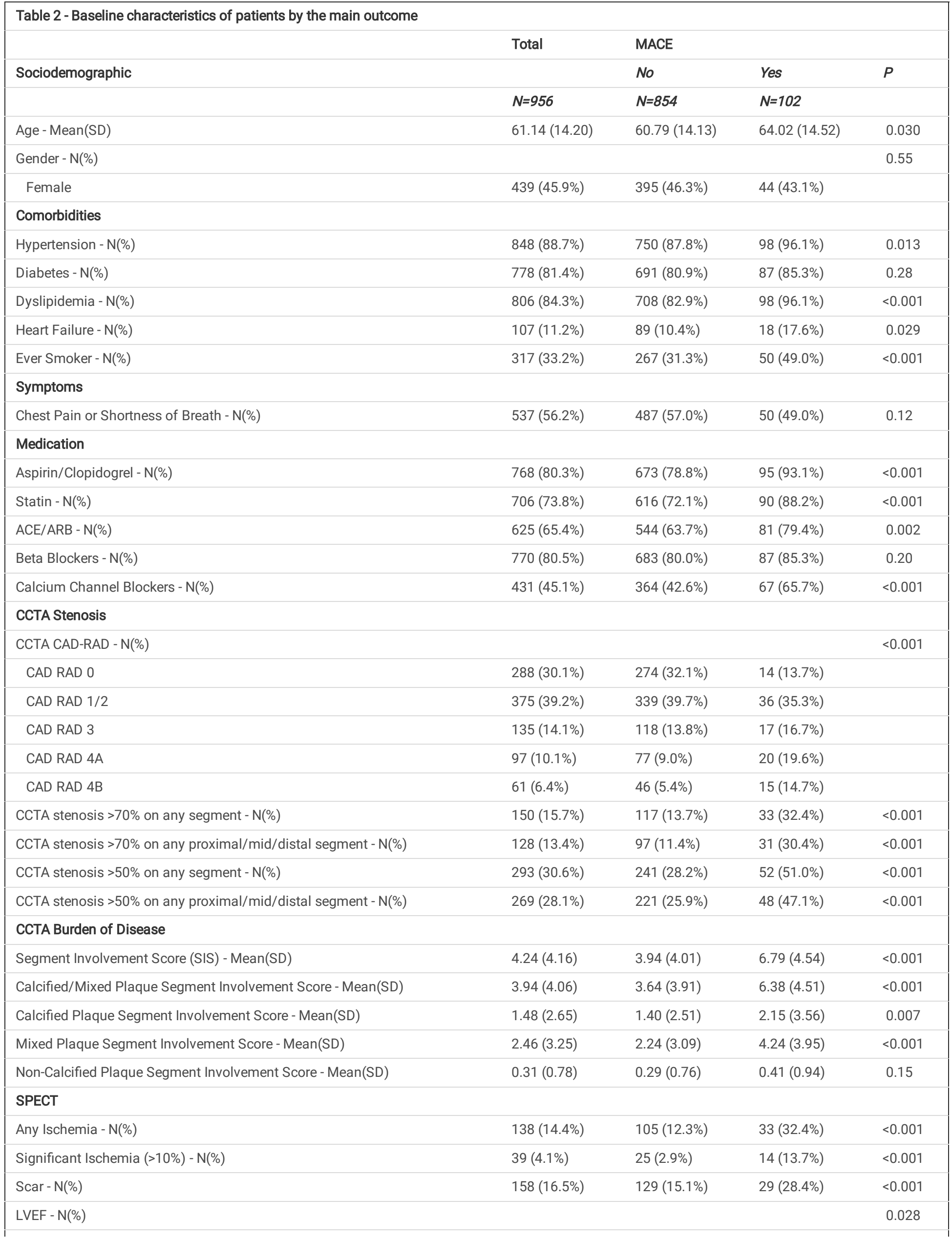




\begin{tabular}{|c|c|c|c|}
\hline$<35 \%$ & $61(6.4 \%)$ & $52(6.1 \%)$ & $9(8.8 \%)$ \\
\hline $35-50 \%$ & 96 (10.0\%) & 79 (9.3\%) & 17 (16.7\%) \\
\hline$>50 \%$ & 799 (83.6\%) & 723 (84.7\%) & 76 (74.5\%) \\
\hline
\end{tabular}

\begin{tabular}{|c|c|c|c|c|c|c|c|c|c|c|c|c|}
\hline & \multicolumn{3}{|l|}{ Model 1.1} & \multicolumn{3}{|l|}{ Model 1.2} & \multicolumn{3}{|c|}{ Model 2.1} & \multicolumn{3}{|c|}{ Model 2.2} \\
\hline & \multicolumn{3}{|c|}{$\begin{array}{l}\text { Base + CCTA obstructive } \\
\text { stenosis }\end{array}$} & \multicolumn{3}{|c|}{ Model $1.1+$ SIS } & \multicolumn{3}{|c|}{ Base + Ischemia by SPECT } & \multicolumn{3}{|c|}{ Model 2.1 + Total SIS } \\
\hline AIC & \multicolumn{3}{|l|}{1207.126} & \multicolumn{3}{|l|}{1185.947} & \multicolumn{3}{|l|}{1199.931} & \multicolumn{3}{|c|}{1177.269} \\
\hline $\begin{array}{l}\text { Global Chi- } \\
\text { square }\end{array}$ & 47.6699 & $p<0.001$ & \multirow[t]{5}{*}{$\begin{array}{l}\text { vs } \\
\text { Base* }\end{array}$} & 70.8491 & $p<0.001$ & \multirow{5}{*}{$\begin{array}{l}\text { vs } \\
\text { Model } \\
1.1\end{array}$} & 54.8651 & $p<0.001$ & \multirow[t]{5}{*}{$\begin{array}{l}\text { vs } \\
\text { Base* }^{*}\end{array}$} & 79.5266 & $p<0.001$ & \multirow{5}{*}{$\begin{array}{l}\text { vs } \\
\text { Model } \\
2.1\end{array}$} \\
\hline C-Statistics & $\begin{array}{l}0.70 \\
(0.64- \\
0.75)\end{array}$ & $p=0.080$ & & $\begin{array}{l}0.74 \\
(0.69- \\
0.80)\end{array}$ & $p=0.008$ & & $\begin{array}{l}0.72 \\
(0.67- \\
0.77)\end{array}$ & $p=0.020$ & & $\begin{array}{l}0.76 \\
(0.71- \\
0.81)\end{array}$ & $p=0.019$ & \\
\hline $\begin{array}{l}\text { NRI- } \\
\text { Continuous }\end{array}$ & 0.28 & $p=0.004$ & & 0.41 & $p<0.001$ & & 0.36 & $p<0.001$ & & 0.36 & $p<0.001$ & \\
\hline $\begin{array}{l}\text { NRI- } \\
\text { Categorical }\end{array}$ & 0.04 & $p=0.260$ & & -0.01 & $p=0.839$ & & 0.03 & $p=0.487$ & & 0.05 & $p=0.287$ & \\
\hline IDI & 0.02 & $p=0.004$ & & 0.02 & $p<0.001$ & & 0.03 & $p<0.001$ & & 0.02 & $p=0.001$ & \\
\hline \multirow[t]{2}{*}{ Relative IDI } & \multicolumn{3}{|l|}{0.70} & \multicolumn{3}{|l|}{0.55} & \multicolumn{3}{|l|}{1.05} & \multicolumn{3}{|l|}{0.44} \\
\hline & $\begin{array}{l}\text { Hazard } \\
\text { Ratio }\end{array}$ & $95 \% \mathrm{Cl}$ & $\begin{array}{l}\mathrm{p}- \\
\text { value }\end{array}$ & $\begin{array}{l}\text { Hazard } \\
\text { Ratio }\end{array}$ & $95 \% \mathrm{Cl}$ & $\begin{array}{l}\mathrm{p}- \\
\text { value }\end{array}$ & $\begin{array}{l}\text { Hazard } \\
\text { Ratio }\end{array}$ & $95 \% \mathrm{Cl}$ & $\begin{array}{l}\mathrm{p}- \\
\text { value }\end{array}$ & $\begin{array}{l}\text { Hazard } \\
\text { Ratio }\end{array}$ & $95 \% \mathrm{Cl}$ & $\begin{array}{l}\mathrm{p}- \\
\text { value }\end{array}$ \\
\hline $\begin{array}{l}\text { CCTA } \\
\text { obstructive } \\
\text { stenosis }\end{array}$ & 2.24 & $\begin{array}{l}1.44- \\
3.49\end{array}$ & $<0.001$ & 1.39 & $\begin{array}{l}0.87- \\
2.21\end{array}$ & 0.171 & & & & & & \\
\hline \multicolumn{4}{|l|}{$\begin{array}{l}\text { Ischemia by } \\
\text { SPECT }\end{array}$} & & & & \multirow[t]{2}{*}{2.76} & \multirow[t]{2}{*}{$\begin{array}{l}1.80- \\
4.24\end{array}$} & $<0.001$ & 2.13 & $\begin{array}{l}1.37- \\
3.31\end{array}$ & $<0.001$ \\
\hline \multicolumn{3}{|l|}{$\begin{array}{l}\text { Segment } \\
\text { Involvement } \\
\text { Score }\end{array}$} & & 1.15 & $\begin{array}{l}1.09- \\
1.21\end{array}$ & $<0.001$ & & & & 1.14 & $\begin{array}{l}1.08- \\
1.20\end{array}$ & $<0.001$ \\
\hline \multicolumn{13}{|c|}{$\begin{array}{l}\text { *Base model included sociodemographic variables (age, gender), cardiovascular risk factors (hypertension, diabetes, dyslipidemia, ever smoking) } \\
\text { symptoms of chest pain or shortness of breath, and early revascularization (PCl or CABG within } 90 \text { days of imaging.) }\end{array}$} \\
\hline \multicolumn{13}{|c|}{$\begin{array}{l}\text { AIC-Akaike information criterion, CCTA - coronary CT angiography, CT - computed tomography, IDI - integrated discrimination index, NRI-net } \\
\text { reclassification improvement, SPECT - single photon emission computed tomography }\end{array}$} \\
\hline
\end{tabular}

\section{Figures}



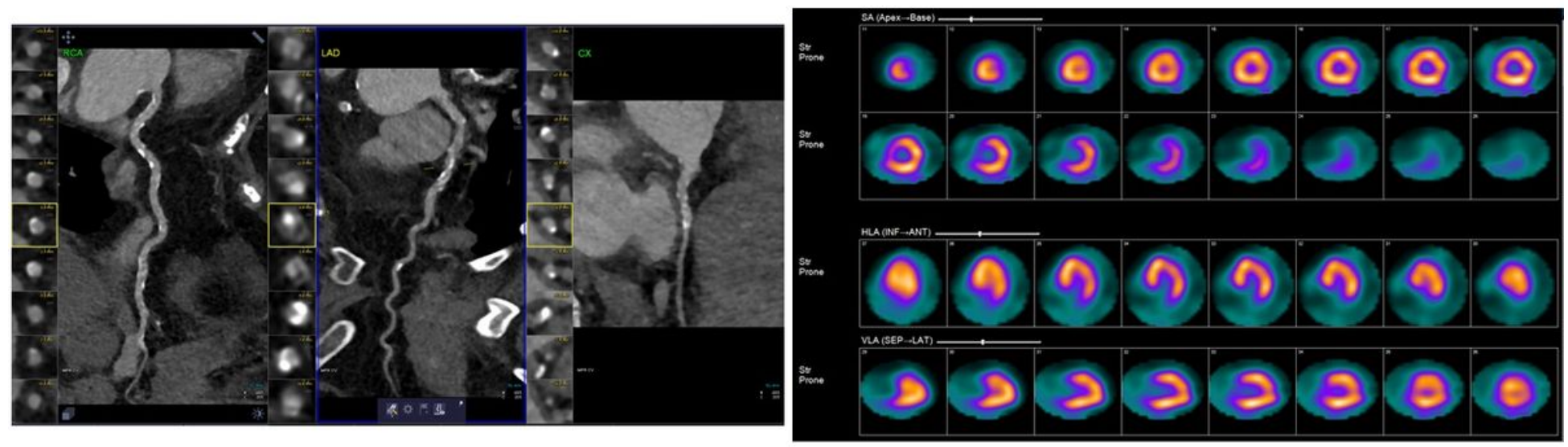

Figure 1

Imaging example from a 73-year-old female with multiple comorbidities. Patient had diabetes, hypertension and dyslipidemia. CCTA showed multiple nonobstructive stenosis and SIS of 11. SPECT showed no ischemia or scar. CCTA - coronary computed tomography angiography, SIS - segment involvement score, SPECT - single photon emission computed tomography
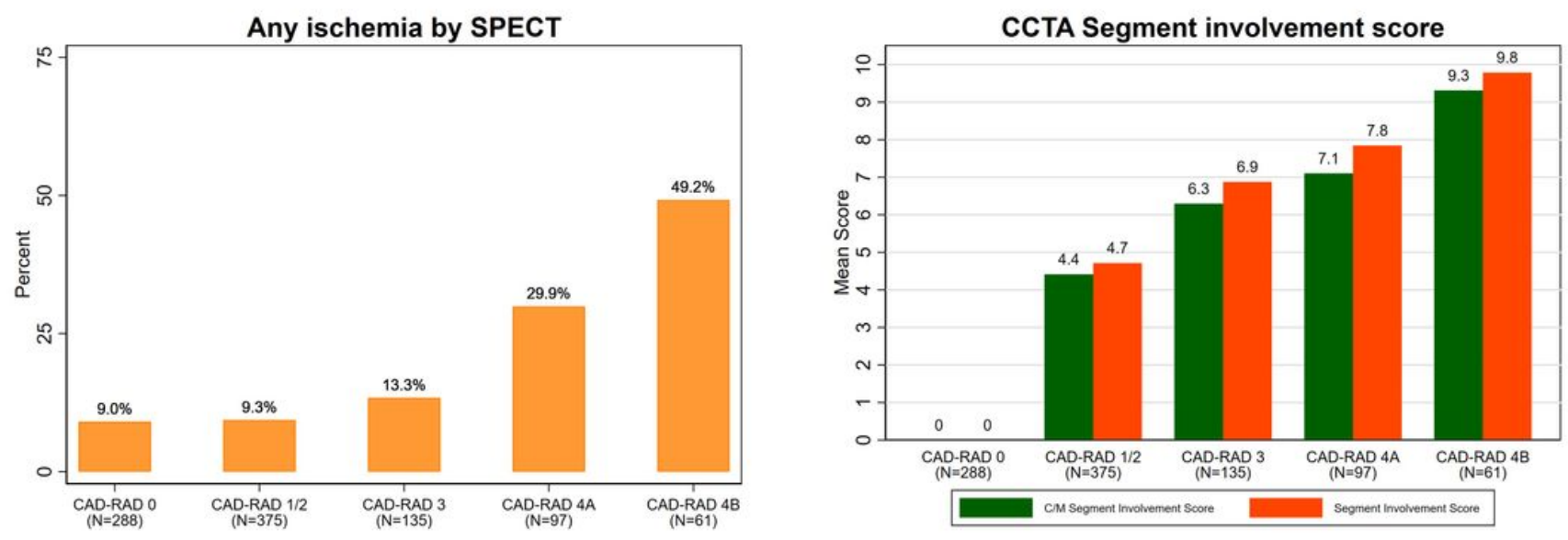

Figure 2 
Mean SIS and percent of patients with any ischemia on SPECT by categories of CAD-RAD The total proportion of patients with ischemia by SPECT and SIS increased across increasing categories of CAD-RAD stenosis CAD-RAD - cardiology coronary artery disease reporting \& data system, CCTA - coronary computed tomography angiography, C/M - calcified/mixed plaque, SIS - segment involvement score, SPECT - single photon emission computed tomography
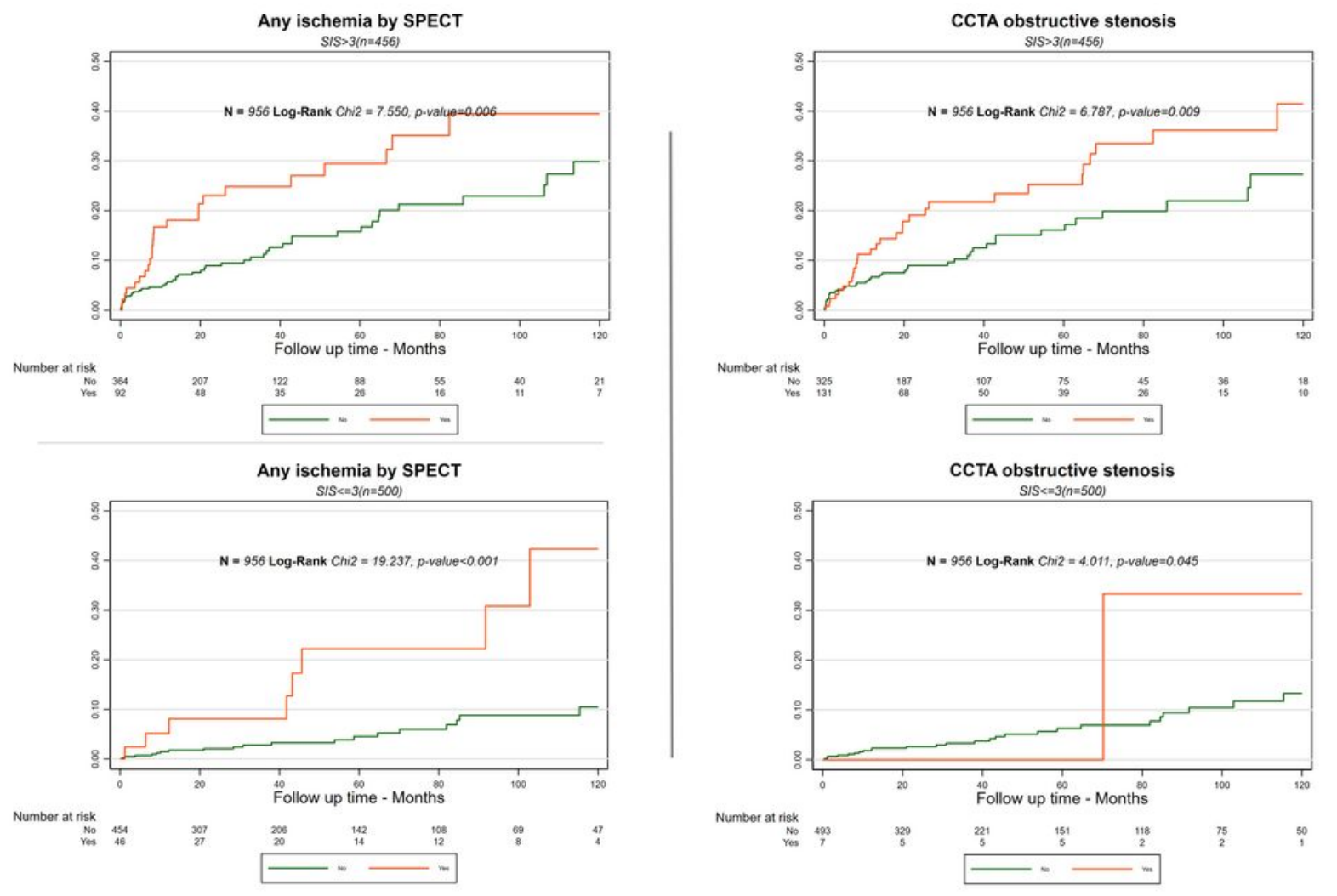

\section{Figure 3}

Kaplan Meier survival estimates for CCTA obstructive stenosis and SPECT ischemia by categories of SIS Both SPECT and CCTA showed high event rates with early separation of the event curves in both categories of SIS. CAD-RAD - cardiology coronary artery disease reporting \& data system, CCTA - coronary computed tomography angiography, SIS - segment involvement score, SPECT - single photon emission computed tomography

\section{Supplementary Files}

This is a list of supplementary files associated with this preprint. Click to download.

- EuroJNMMICTvsSPECTSupplementalfiles.docx 